\title{
Professional geology and regulation
}

\begin{abstract}
Compared to other professionals, geologists have been slow in establishing regulatory frameworks to help maintain standards of professional conduct and to promote confidence among employers and the general public. Firmly founded in national or provincial geological surveys and learned societies which date back to the middle of the last century, it is only in the last 30 years or so that geological professionals have recognised the need for some form of registration. Although wide-ranging systems have been adopted in different countries to achieve this end, it is important that all practioners of geology are seen to be properly qualified and able to deliver unbiased work products of high quality.
\end{abstract}

\section{Introduction: the development of geology}

Geology as a profession and science has its roots in the late 18 th century, first in the United Kingdom (UK), and then more widely in the developing world. During the early 19th century, great advances in Europe were made in geology by such men as Lyell, Murchison, Darwin and Sedgewick while Silliman and others in the United States of America were developing and building on the ideas of the UK founding fathers William Smith and James Hutton.

The increasing interest in. and awareness of, the importance of geology led to the founding of the Geological Society of London in 1807, the first such society in the world, and to the establishment of the UK Geological Survey as a branch of the Ordnance Survey in 1835-also one of the first such organisations in the world.

At this time in the early 19 th century, there were perhaps as few as ten individuals in the UK earning their living through a knowledge of geology. As might be suspected, there were many amateur geologists and those who combined the role of geologist with that of, for example, mining engineer, civil engineer and even cleric (The Geological Society, 1994).

The growing interest in geology in the USA, in the early part of the 19th century, also led to establishment of formal organisations such as state geological surveys. For example, Olmsted, educated in geology at Yale University under the tutelage of Benjamin Silliman, became the Director of the North Carolina State Geological Survey in 1824 , predating the UK Geological Survey by a decade. Early leaders in geology, as with David Dale Owen, also were eminent in developing formal geological organisations. Furthermore, Owen for example, was Director of the Indiana Geological Survey during 1838-39 and returned in 1859-60. By 1860,30 state geological surveys were established. State geological surveys share credit for many advancements in geology, including being the foundation for the American Institute of Professional Geologists (AIPG), both in concept and in Founding and Charter Members.

In the 19th and the first half of the 20th centuries, the increasing number of schools of geology at universities, the utilisation of natural resources to meet industrial growth and the needs of the European countries and their empires led to a gradual increase in the number of professional geologists. This was also supported by the increasing requirements of the petroleum industry to find and develop new resources.

There has been a dramatic increase in the number of graduate geologists attending universities, polytechnic and technology estab- lishments worldwide over the past 40 years. This increase has arisen partly in response to enhanced opportunities within industry (mineral extraction, water, energy and civil engineering) based largely on the demand for raw materials. A wide recognition of the essential role that earth scientists play in environmental monitoring, protection and conservation, leading to a greater public awareness of geology, has also occurred especially during the last two decades.

Many activities, including the protection of water resources and waste disposal, require geological advice and may have an impact on the environment. Mining, hydrocarbon production, quarrying and construction development all cause environmental changes.

\section{The role of professional bodies and the need for regulations in geology}

Geologists often work in association with other professionals such as civil, mining, petroleum and water engineers, chemists, physicists, metallurgists, planners, accountants and lawyers many of whom have had their own professional institutions for years. These bodies have set standards by which the capability, ethics, academic training and experience of a member may be judged and the welfare of the public protected. The standards frequently are statutory, although some professional bodies are self governing and not subject to government legislation.

Among the most important roles of professional bodies are:

- as a provider of a common voice on matters of national importance relevant to the particular profession;

- as a central player in public debates and in the raising of standards of education, training and professional practice.

- as an enhancer of the standing of its members among the general public and government agencies, both nationally and internationally.

In the last 30 years there has been an increasing awareness of the need for professional regulation to strengthen the geological sciences as a profession and to protect the health, safety and welfare of the public.

Registration of geologists generally implies that the registrant has certain identified minimum qualifications that have been examined. However, because the term 'registration' is defined in different ways in different statutes and from one professional body to another, there is some confusion among geologists and the general public about what it implies. The ways in which various criteria and legislative procedures are used in registration may be illustrated by the following:

Academic qualification-There is a relatively widespread reliance on academic degrees, based on the assumption that a degree implies an acceptable level of competence.

Recognition by professional peers ('peer review') - In many jurisdictions, professional organisations examine and endorse quali fications. Though it may not be necessary to be so qualified to practice, the use of such titles as Board Certified and Charteres generally is restricted. Over time, the titles have acquired professional standing and have been formalised by government statute or charter in some jurisdictions, for example, in parts of the European Union (EU). In other places, endorsements may be recognised, but not the specific or exclusive right to exercise the responsibility.

Definition of a profession and its practitioners (definitions acts) - Some states (sovereign authorities) define a profession and its practitioners by statute or common law. Definitions usu- 
ally are rather broad and may stipulate that only such a person be employed for certain assignments. However, definitions are intended more to alert the consumer than to serve as an enforcement mechanism.

Titles conferred on practitioners (tille acts) - In some states, the state itself qualifies practitioners, usually through a board. It grants a title such as 'certified' and restricts its use. Only the title is restricted, not the practice. While such procedures do not prevent an untitled person from practising. some agencies may require that reports presented to them be prepared or approved by a person who does hold the title.

State licensing (practice acts) - These are similar to title acts, but restrict practice to those qualified by the state or other authority.

Speciality certification and licensing - A few states regulate specialities as an add-on to general professional regulation. This regulation may be by definition, title. or practice.

Comity and reciprocily-Both comity and reciprocity are frequently and mistakenly referred to as reciprocity. Comity is a courtesy, not a right, granted out of goodwill, by which persons recognised by one entity have access to recognition by another on a case-by-case basis. Reciprocity is mutuality. It denotes the relation between entities when each gives all of the citizens or members of the other certain privileges provided that their own members enjoy similar privileges.

\section{Examples of regulation practice}

In some parts of the world, the geological profession is regulated by law, as in Italy, Spain, certain countries of Latin America and states of the USA. The rationale given is that it gives greater protection to the public. It offers the designated profession an exclusive right to a title such as 'geologist', a broad definition of practice and usually an exclusive right to practice in a defined geographical area. The public is therefore deemed to be protected from unskilled practitioners by restricting practice to designated professionals.

In Europe, EU Directive 89/45 (FFC 1989) requires member countries to accept mutual recognition of qualifications. The stated purpose is to enhance the free movement of professionals from state to state. Furthermore, the directive supports the idea that member countries designate existing organisations (e.g. the Geological Society of London in the UK, the Union Française de Géologic in France) to regulate the geological profession in the respective countries.

The European Federation of Geologists (EFG), founded in 1980 (EFG 1992), endorsed this EU directive as a means of achieving freedom of movement of geologists within Europe. Similar moves towards reciprocity between states, are being made in the USA. To further this effort, the EFG have established the awarding of the title 'European Geologist' to those members of the Associations within the Federation who have a minimum of 8 years of education and experience as practising graduate geologists. The awarding of such a title at the institutional level is an additional way of enhancing the free movement and achieving 'reciprocity'. for European geologists.

In Australia there are a number of learned societies, professional groups and geological associations that are represented by the Pan-Australian Organisation of the Australian Geoscience Council. This council has the dual task of informing geoscientists of developments and trends in their professional area and unifying geoscientists in order to enable governments, industry and the public to obtain a heightened awareness of geoscience-related matters (Roberts, 1984). Unification of geoscientific organisations in Australia in the early $1980 \mathrm{~s}$ was seen as vital, because of the effects that this would have on improving the status of geoscientists, and the circumstances including lobbying, public relations and education. Currently, the two principal organisations for the Mining Industry (The Australian Institute of Mining and Metallurgy and the learned and professional geological organisations, The Australian Institute of Geoscientists) are following similar and converging paths in the task of establishing criteria and methods for the registration of geoscientists.
On the African continent, geologists working in Kenya, through the Geological Society of Kenya have, as recently as late 1994. established a mechanism for setting-up a Geologists' Registration Board. This was accomplished under a Kenyan Act of Parliament 'The Geologists Registration Act 1993' intended to ensure that the performance of geological work is restricted to geologists registered under the act. The Board has the responsibility for regulating the activities and conduct of registered geologists. This legislation will apply to those geologists having permanent residence in Kenya as well as those secking temporary residence to carry out specific work. The Board consists of four persons appointed by the Minister plus three persons appointed by the Geological Socicty of Kenya.

Recently, the Canadian Council of Professional Geologists Implementation Task Foree (The CCPG-ITF), consisting of ten representatives from all provinces and territories except Prince Edward Island and Yukon Territory (BC, AB, NWT, SK, MB, ON, QC, NB, NS \& NF), has held two meetings. The first objective of the CCPGITF will be to incorporate the Canadian Council of Professional Geoscientists (CCPG) as a federal not-for-profit corporation and it is expected that this will be accomplished towards end of 1996. The mission of the CCPG will be to provide representation and coordination for the provincial and territorial associations of professional geoscientists on national and international issues, including national standards, mobility, human resource issues and public awareness. The CCPG will be similar to, and maintain close relations with, the Canadian Council of Professional Engineers, which provides analogous services for the Canadian engineering professions. Priorities for the CCPG (and, in the interim, for the CCPG-ITF) will be to assist Canadian associations that register or cortify geoscientists (geologists and geophysicists) in establishing academic and other standards for registration/certification and to enhance mobility of Canadian professional geoscientists and transferability of registration among jurisdictions.

A new Engineering and Geosciences Professions Act received royal assent in the province of Saskatchewan at the beginning of May 1996. bringing the number of jurisdictions that register (provide restricted right to practice) to five. $A$ similar act received first reading in the Nova Scotia legislature in May and will probably be passed at the fall sitting. New acts to register geoscientists under combined engineering-geoscience legislation are expected to be introduced into the legislatures in Manitoba and Ontario before the end of 1996 and similar legislation is expected in New Brunswick in 1997. In Ontario, the Association of Geoscientists of Ontario has been formed as an intermediate step to collaborate with the Association of Professional Engineers of Ontario in developing the new act. The situation in Quebec is unchanged; the Association of Professional Geologists and Geophysicists of Quebec is awaiting proclamation of their inclusion under right-to-title (certification) legislation that was approved by the provincial assembly three years ago.

In the United States of America, professional registration of geologists by states has been in operation for some 35 years. The development of the registration principles has progressed at different rates and in different ways depending on the needs of cach state (Table 1).

Twenty-six of the United States have statutes related to the professional practice of geology. Of these, three have definition acts. Certification by the American Association of Petroleum Geologists" Division of Professional Affairs (AAPG/DPA); American Institute of Professional Geologists (AIPG); and Society of Independent Earth Scientists (SIPES) generally have membership requirements that meet or exceed the definition act requirements.

Four states have title acts: Alaska recognise AIPG's certification in its statutes; Virginia and Wyoming (and soon Indiana) require written examinations. (Wyoming's Act calls titled persons 'licensees', even though it is not a practice act. However, Wyoming has changed its statute to require that certified geologists be employed for specified tasks. The effect is to change from a 'title' to a 'practice' act in part).

Nineteen of the states have practice acts. All but Delaware and Tennessee currently require written examinations. 
Five states allow speciality certification. That option has been implemented in California and Oregon, but not in Arkansas, Georgia and Missouri.

Some states exempt certain specified geological activities from regulation, usually those related to petroleum and other mineral exploration and extraction.

The remaining 24 states have no statutory regulation of geologists. However a hotch-potch of legislation and regulations governs specific activities in which geologists often engage. Most such regulations, created by various government agencies are related to environmental work.

There are active movements in several states to enact statutory regulations of professional geologists. Some state legislatures and professional geologists however, have resisted professional regulation.

Reciprocity, on the matter of some states regulating the profession of geology in the USA, working through the National Association of State Boards of Geology (ASBOG), are striving to establish inter-state comity, if not true reciprocity. Most states' statutes do provide for some form of comity or reciprocity. Until recently, however, the only thing approaching true reciprocity, established by statute, has been between Alaska and Indiana through statutory recognition of AIPG certification. The next nearest approach is between the few states whose Boards recognise each others examinations as being equivalent to, or the same as, their own. Such recognition is enabled, but not established, by statute.

Many countries accept professional geologists by academic qualification or recognition by professional peers. The European Parliament has mandated that regulation of all professions (including health care) is not to be by government agencies, but by professional organisations designated by the governments. In the USA, as shown above, the opposite practice prevails. This is primarily caused by legal interpretations of the laws concerning the differences in authority between individual states, as sovereigns, and professional organisations, as voluntary associations lacking sovereign authority. Some states have the power within their constitutions to delegate authority, and have done so, e.g. Alaska. Most, however, either do not or have not.

\section{Geologists and the public}

The need for geoscientists to present a united front to the public is critical. It is imperative that governments and the public be informed on the increasingly important role that geologists have in a wide range of topics that affect every-day life, wealth creation and environmental issues. Geologists must also be made aware of the needs of those they may be advising. As professionals they can have a greater impact if they are seen by governments and the public as being properly qualified and creating quality work products free of bias.

\section{References}

Roberts, J, ed., 1984. Report No. 268 Australian Geoscience 1984 Annual Report of the Australian Geoscience Council Inc. The Council of Earth Sciences Societies in Australia. Dept. of Resources \& Energy. Bureau of Mineral Resources Geology \& Geophysics. Editor John Roberts. Canberra 1985 .

EEC, 1989, First general directive on the mutual recognition of professional qualifications $(89 / 45 / \mathrm{EEC})$.

EFG, 1992, EFG - its aims, organisation and achievements. European Federation of Geologists, Paris, France.

Devenny D W, 1994, A response to new directions in legislating professional practices, Association of Professional Engineers, Geologists and Geophysicists of Alberta, 1994.

The Geological Society, 1994, Rules of admission and guidance notes for fellowship, The Geological Society of London.

Theuri, F G, 1995, Registration of Geologists in Kenya, Nairobi (personal communication, unpublished).

Williams, G D, 1996, Canadian council of professional geoscientists: implementation task force, Alberta (personal communication, unpublished).
Table 1 States regulating geologists in the USA.

\section{By definition: \\ Colorado \\ Kansas \\ Oklahoma}

By title:

Alaska

Indiana

Virginia

Wyoming
By practice:

Alabama

Arizona

Arkansas

California

Delaware

Florida

Georgia

Idaho

Illinois

Kentucky

Maine

Minnesota

Missouri

North Carolina

Oregon

Pennsylvania

South Carolina

Tennessee

Wisconsin
Richard A Fox is currently Manager of the Land Search and Exploration Department, Ready Mixed Concrete (UK) Ltd. He is a past President of the European Federation of Geologists, and past VicePresident of the Geological Society of London.

William $V$ Knight is currently Executive Director of the American Institute of Professional Geologists and previously was a geological consultant in Tulsa, Oklahoma, USA

James Williams is State Geologist and Director of the State of Missouri Department of Natural Resources Division of Geology and Land Survey. He is a member of the Missouri Board of Geology which he represents on the National Association of State Boards of Geology.
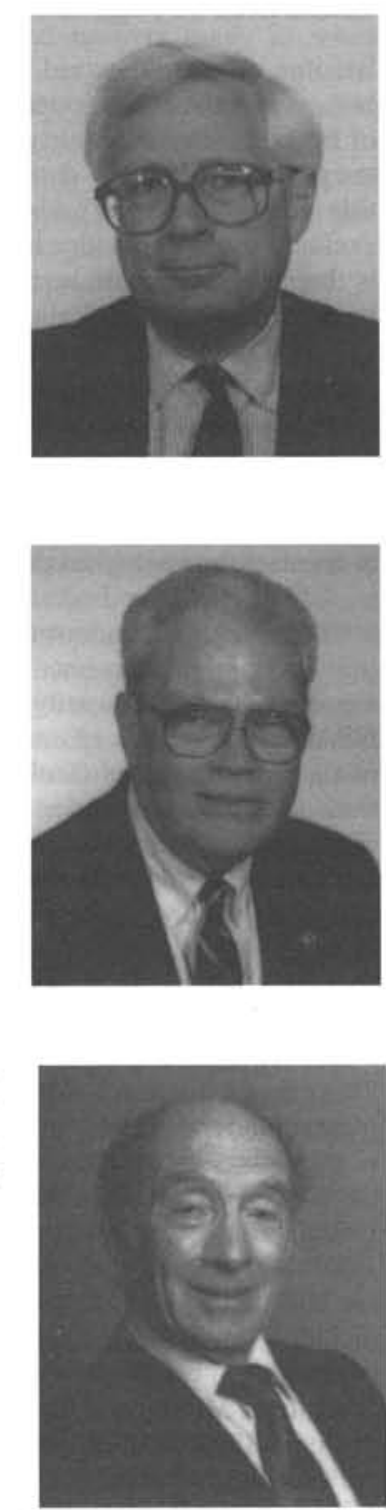